\title{
Growth response of Pinus pinaster Ait. to climatic variables in central Spanish forests
}

\author{
Stella M. BoGINO ${ }^{1,2 *}$, Felipe BRAVO ${ }^{1}$ \\ ${ }^{1}$ Departamento de Producción Vegetal y Recursos Forestales, Universidad de Valladolid, Avda. de Madrid 44, 34004 Palencia, Spain \\ ${ }^{2}$ Departamento de Ciencias Agropecuarias. Facultad de Ingeniería y Ciencias Económico-Sociales, Universidad Nacional de San Luis, \\ Avda. 25 de Mayo 384, 5730 Villa Mercedes, San Luis, Argentina
}

(Received 29 January 2008; accepted 2 April 2008)

\begin{abstract}
-
- The effect of climatic variables (temperature and precipitation) on radial growth of the Mediterranean Maritime pine (Pinus pinaster Ait.) was studied using dendrochronological techniques in the Iberian Peninsula.

- Ten tree-ring width chronologies, along the central distribution area of the species, were built. Chronology variability was analysed using Principal Component Analysis (PCA) for the period 1952-2005.

- The first principal component (PC1) explained $56 \%$ of tree-growth variability. Tree-growth association with climate was analysed at regional and local scales using correlation coefficient and bootstrapped response functions.

- Radial growth at both scales was positively correlated with rainfall during and prior to the growing season at all sites, and with summer rainfall before the growing season at five sites. Mean temperature effect changed according to the sampling site, from non-significant at the highest sites to significant (positive relationship in winter) at the lowest sites. Growth season temperature also had a negative effect.

- The Kalman filter was applied to estimate changing association between growth and climate over-time. Results suggested a change in association, initiated in the $80 \mathrm{~s}$, from non-significant to significant $\left({ }^{*} p<0.05\right)$ at six of the sampling sites.

- Pinus pinaster is an accurate species for analysing tree-growth association with climate and for studying plant behaviour under global change conditions.

dendroclimatology / Mediterranean Maritime pine / tree-ring / response function / Kalman filter

Résumé - L'influence des variables climatiques sur la croissance radiale de Pinus pinaster Ait. dans les forêts de l' Espagne centrale.

- L'influence des variables climatiques (températures et précipitations) sur la croissance radiale du pin maritime (Pinus pinaster Ait.) a été étudiée en utilisant des techniques dendrochronologiques dans la péninsule Ibérique.

- Dix chronologies de largeur de cerne ont été établies tout au long de la zone centrale de distribution de l'espèce. La variabilité des chronologies a été étudiée par une Analyse en Composantes Principales (PCA) pour la période 1952-2005.

- La première composante principale (PC1) a expliqué $56 \%$ de la variabilité de la croissance des arbres. L'association entre la croissance des arbres et le climat a été analysée à l'échelle locale et régionale en utilisant un coefficient de corrélation et une méthode de rééchantillonnage.

- La croissance radiale à ces deux échelles a montré une corrélation positive avec les précipitations survenues pendant et avant la saison de croissance dans tous les sites et avec les précipitations estivales survenues avant la saison de croissance dans cinq sites. L'effet de la température moyenne a varié en fonction de l'altitude des sites, en étant non significatif dans les sites les plus élevés et positivement significatif en hiver dans les sites les plus bas. La température de la saison de croissance a également eu un effet négatif.

- On a appliqué le filtre de Kalman pour estimer les variations temporelles de l'association variable entre la croissance et le climat. Les résultats ont suggéré que cette association est passée, dans les années 80 , de non significative à significative $\left({ }^{*} p<0,05\right)$ dans six sites d'échantillonnage.

- Pinus pinaster est une espèce adéquate pour analyser l'association entre la croissance des arbres et le climat, et pour étudier le comportement de l'espèce dans des conditions de changement global.
\end{abstract}

dendrochronologie / pin maritime méditerranéen / cerne / fonction de réponse / filtre de Kalman

\section{INTRODUCTION}

Understanding the growth and productivity response to climate change is a key issue in forest modelling and forestry. It is also crucial in enhancing past climate reconstructions made using dendrochronological techniques. Tree ring growth is influenced by several simultaneous environmental factors: solar radiation, temperature, water precipitation, soil nutrient content, etc. Depending on conditions and species, one or more of these factors can become limiting for tree growth (Fritts, 1976). Climate variability often explains past tree growth (Hughes, 2002), helping in the projection of future growth responses in the context of climate change (Yeh and Wensel, 2000).

\footnotetext{
* Corresponding author: sbogino@fices.unsl.edu.ar
} 
Table I. Ecoregion classification, geographical position and mean basal area of ten Pinus pinaster sampling sites across its natural distribution area in the Iberian Peninsula.

\begin{tabular}{|c|c|c|c|c|c|c|}
\hline Site & Code & Ecoregion & Latitude & Longitude & Altitude (m) & $\mathrm{BA}\left(\mathrm{m}^{2} \cdot \mathrm{ha}^{-1}\right)$ \\
\hline P42201 & $2 \mathrm{a}$ & Duriense & $41^{\circ} 33^{\prime} 43^{\prime \prime}$ & $02^{\circ} 55^{\prime} 17^{\prime \prime}$ & 1012 & 53.84 \\
\hline P42002 & $2 b$ & Duriense & $41^{\circ} 34^{\prime} 03^{\prime \prime}$ & $02^{\circ} 35^{\prime} 51^{\prime \prime}$ & 1059 & 34.84 \\
\hline P44002 & $3 b$ & Catalano-Aragonesa & $40^{\circ} 19^{\prime} 07^{\prime \prime}$ & $01^{\circ} 21^{\prime} 18^{\prime \prime}$ & 1437 & 40.17 \\
\hline P44005 & $3 c$ & Catalano-Aragonesa & $40^{\circ} 20^{\prime} 47^{\prime \prime}$ & $01^{\circ} 21^{\prime} 54^{\prime \prime}$ & 1364 & 45.73 \\
\hline P44204 & $3 d$ & Catalano-Aragonesa & $40^{\circ} 20^{\prime} 01^{\prime \prime}$ & $01^{\circ} 21^{\prime} 26^{\prime \prime}$ & 1232 & 34.33 \\
\hline P16106 & $4 \mathrm{~b}$ & Litoral-Mediterránea & $39^{\circ} 50^{\prime} 17^{\prime \prime}$ & $01^{\circ} 16^{\prime} 11^{\prime \prime}$ & 970 & 36.66 \\
\hline P16202 & $6 a$ & Manchega & $39^{\circ} 49^{\prime} 48^{\prime \prime}$ & $01^{\circ} 17^{\prime} 38^{\prime \prime}$ & 1135 & 41.69 \\
\hline P16208 & $6 b$ & Manchega & $39^{\circ} 50^{\prime} 28^{\prime \prime}$ & $01^{\circ} 17^{\prime} 54^{\prime \prime}$ & 1090 & 34.74 \\
\hline
\end{tabular}

Tree-ring widths of conifers offer some of the best climatological reconstructions of semiarid regions (Schweingruber, 1996), as in the case of annual precipitation estimates in Mediterranean climates (Tessier et al., 1997). On the other hand, different climatic variables (mainly derived from precipitation and temperatures but also derived from atmospheric pressure balance) can be used to express climatic oscillation and to derive relationships between tree growth parameters and climatic signal (D’Arrigo and Jacoby, 1992; Jones et al., 1997).

The Mediterranean climate is characterised by summer drought and high inter-annual variability of precipitation and temperature. Projections of climate change impact on the European distribution of higher plants in 2050 suggest that the Iberian Peninsula could be one of the most vulnerable areas for species lost (Bakkenes et al., 2002). Climate shifts have already taken place in the region, as exemplified by the reduction of rainy days by 50 and $30 \%$ over the southern coast of Spain and the Pyrenees in the last century, respectively (EstebanParra et al., 1998; Rodrigo et al., 2000). The mean annual temperature has increased about $1.6^{\circ} \mathrm{C}$ in the Iberian Peninsula over the last century (IPCC, 2007; Parry, 2000).

The Mediterranean Maritime pine (Pinus pinaster Ait.) is a characteristic species in Mediterranean forests, with its main populations located in the Iberian Peninsula (Blanco et al., 1997). This species shows a wide ecological range (Nicolas and Gandullo, 1967), being able to survive under high or low temperatures, under regular or variable rainfall as well as under severe droughts. It is adapted to the extremely cold winters of the continental climate in central Spain and to the mild, temperate ones of the Atlantic coast in the western Iberian Peninsula (Alía et al., 1996; Blanco et al., 1997).

In Spain, Pinus pinaster constitutes pure and mixed woodlands that are both natural ( 1 million ha) and planted ( 0.6 million ha) (DGCN, 1998; 2002). These woodlands are mainly spread over the northern Spanish plateau up to $1500 \mathrm{~m}$. In this area, the climate is characterised by irregular rainfall, between and within years, and high temperatures in summer. The soils are sandy and rocky and very well drained. Even though Pinus pinaster pine had been used widely on plantations in the Iberian Peninsula, this species grows naturally in some ar- eas, where it is the best adapted woody species (Blanco et al., 1997). Fossil Pinus pinaster cones and pollen dating from the Superior Pliocene have been found in the Iberian Peninsula, suggesting a pre-Mediterranean origin for this species and evolution in tropical-like environments that gradually incorporated seasonal aridity (Di Castri, 1981). Authors suggest that the Iberian System is the natural origin and centre of distribution for this species (Blanco et al., 1997).

Pinus pinaster has rarely been used for dendrochronology and dendroclimatology studies because stands older than 100 years are very difficult to find. In addition, trees from the lower mountain level often have false rings and most trees have been damaged by resin harvest in the past (Schweingruber, 1993).

The relationship between growth indices and climatic variables is essential for predicting the future growth trend of Pinus pinaster. Given the high vulnerability of Iberian plant communities to climate change and the importance of Pinus pinaster forests in this region, understanding the growth response of this species to past climate variability can help us to explore how its populations, and the ecosystems they dominate, will behave in the dramatic climatic shifts expected in future. The objectives of this paper are to analyse the relationship between Pinus pinaster tree ring width and climatic variables (precipitation and temperature) at the (a) regional and (b) local scales, and (c) to explore possible shifts in the association between these climate variables and tree growth over time as a result of changing environmental conditions.

\section{MATERIALS AND METHODS}

\subsection{Study sites}

Ten sampling sites were selected from four different bioclimatological ecoregions where Pinus pinaster grows in the Iberian Peninsula. Each ecoregion has common physiographic, climatic and lithological characteristics (Elena Roselló et al., 1997) (Tab. I and Fig. 1). 


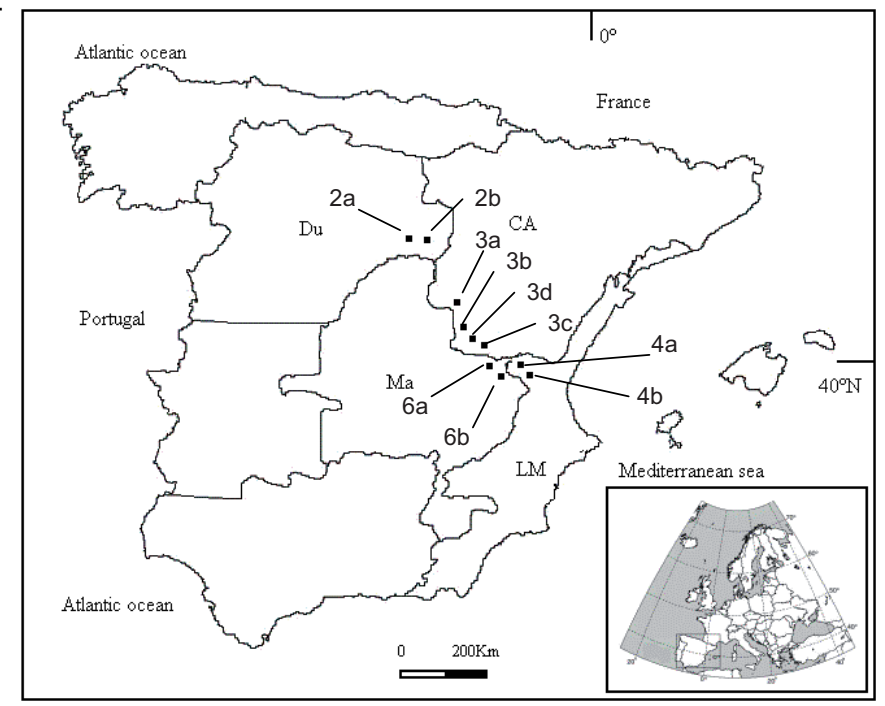

Figure 1. Sampling sites set up across the natural distribution area of Pinus pinaster in the Iberian Peninsula. Du: Duriense; CA: CatalanoAragonesa; Ma: Manchega and LM: Litoral-Mediterránea bioclimatological ecoregions (Elena Roselló et al., 1997).

Table II. Meteorological station data from the Agencia Estatal de Meteorología (Spain) used in this study. Rainfall: Annual precipitation; Temp.: Mean monthly temperature; Period: Time with data available. Ecoregion: CA: Catalano-Aragonesa; LM: Litoral-Mediterránea; Ma: Manchega and Du: Duriense bioclimatological ecoregions.

\begin{tabular}{lccccccc}
\hline Meterological station & Latitude & Longitude & Altitude $(\mathrm{m})$ & Rainfall $(\mathrm{mm})$ & Temp. $\left({ }^{\circ} \mathrm{C}\right)$ & Period & Ecoregion \\
\hline El Burgo de Osma & $41^{\circ} 35^{\prime} 10^{\prime \prime}$ & $03^{\circ} 04^{\prime} 02^{\prime \prime}$ & 895 & 529.5 & 10.54 & $1932-2005$ & CA \\
Cuenca & $40^{\circ} 04^{\prime} 00^{\prime \prime}$ & $02^{\circ} 08^{\prime} 17^{\prime \prime}$ & 956 & 541.42 & 12.43 & $1956-2005$ & LM \\
Pantano de la Toba & $40^{\circ} 13^{\prime} 19^{\prime \prime}$ & $01^{\circ} 55^{\prime} 33^{\prime \prime}$ & 1154 & 764.68 & 10.22 & $1944-2005$ \\
Soria (Observatorio) & $41^{\circ} 46^{\prime} 00^{\prime \prime}$ & $02^{\circ} 28^{\prime} 00^{\prime \prime}$ & 1082 & 418.34 & 10.66 & $1944-2005$ & Ma \\
\hline
\end{tabular}

\subsection{Field work and laboratory methods}

In the summer of 2006, two cores were extracted at $1.30 \mathrm{~m}$ above ground level from fifteen dominant and co-dominant trees at each sampling site. Tapped trees were avoided because their growth was likely to have been affected by resin extraction, confounding possible climatic signals. Cores were glommed on channelled wood, dried for two weeks and polished with progressively thinner sandpaper. Tree-rings were dated to establish correctly the calendar year in which a treering was formed. Dating was achieved using a binocular microscope following standard dendrochronological techniques (Cook and Kairiukstis, 1990; Fritts, 1976; Stokes and Smiley, 1968;). The cores in transverse sections were scanned at high resolution (2000 dpi) with an Epson Expression 1640 XL scanner with $0.01-\mathrm{mm}$ accuracy, and rings were measured using the WinDENDRO program (Regent Instruments Inc., 2002).

\subsection{Climatic data}

Monthly precipitation and mean monthly temperature, provided by the Agencia Estatal de Meteorología (Spain), were selected to assess the climate-growth relationship. Meteorological data from four meteorological stations placed within

\section{El Burgo de Osma - Soria (895 m)}

Lat $41^{\circ} 35^{\prime} 10^{\prime \prime} \mathrm{N}$ - Long. $03^{\circ} 04^{\prime} 02^{\prime \prime} \mathrm{W}$

[81] $\quad 10.54^{\circ} \mathrm{C} \quad 529.5 \mathrm{~mm}$

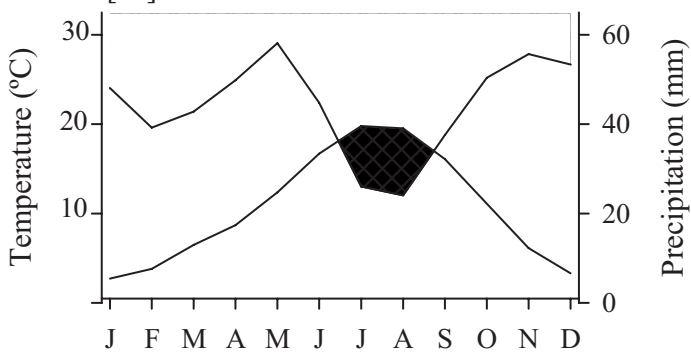

Figure 2. Climate diagram of El Burgo de Osma meteorological station (1932-2005).

$30 \mathrm{~km}$ of the sampling sites have been used (Tab. II). The climate-diagram of the El Burgo de Osma meteorological station is provided as an example (Fig. 2). The data recorded cover a period of at least 50 years. The data from the four meteorological stations were averaged to obtain a regional climatic record to be applied in the regional dendroclimatic analysis. The HOM component (Homogeneity of Meteorological Data) of the Directory Program Library for Dendrochronology 
(Holmes, 1983, available at www.ltrr.arizona.edu) was used to determine the homogeneity of the climatic variables.

\subsection{Statistical analysis}

The v6.06P COFECHA program (Grissino-Mayer, 2001; Holmes, 2001) (available at www.ltrr.arizona.edu) was applied to assess measurement and dating accuracy. This program calculates the Pearson correlation indices between the indexed tree-ring series and a master reference chronology in a series of consecutive, partially overlapped segments of a length specified by the user. Absolute dating is essential for any dendroclimatological study, and it is impossible to compare climatic variables in one specific year with tree-ring growth if the individual tree-ring series are not dated correctly.

To eliminate biological trends in tree-ring series and to minimize growth variations that are not shared by most trees (Fritts, 1976), the v6.05P ARSTAN program (Cook and Holmes, 1984; Holmes, 2001) (available at www.ltrr.arizona.edu) was used. Standardisation removes geometrical and ecological trends while preserving inter-annual high-frequency variations that are presumably related to climate. To obtain a master chronology at each study site, the standardised series were averaged. These temporal series or master chronologies expressed the annual variations in Pinus pinaster radial growth at the population level in each sampling site.

Chronology quality was evaluated using mean sensitivity (MS), which is the degree by which one or more casual factors are reflected by a tree-ring series (Schweingruber, 1996); signal-to-noise ratio (SNR), the proportion of the variability explained by climate or other casual factors divided by the residual or unexplained variability (Fritts and Swetnam, 1989); and expressed population signal (EPS), which describes how a finite sample estimates the hypothetical infinite population (Briffa, 1995; Wigley et al., 1984). Chronology was considered confident with an EPS value higher than 0.85. The common variance between all residual chronologies was analysed using a Principal Component Analysis for the common growth period 1952-2005 (Sokal and Rohlf, 1995) using Infostat V.2 (Di Rienzo et al., 2002). The variance explained by the first principal component (PC1) was used as an indicator of the similarity among the chronologies. $\mathrm{PC} 1$ was used as a regional chronology of Pinus pinaster in central Spain.

To determine the climatic variables that control $P i$ nus pinaster radial growth, mean monthly temperature and monthly rainfall were compared with the regional chronology (PC1) and the local chronologies at each sampling site. PC1 was related with the average of the meteorological station data. Each site chronology was compared with the meteorological station closest to the analysed site. The period explored was from the previous June to September of the current growth year. The v 5.17 PRECON program (Fritts, 1999) (available at www.ltrr.arizona.edu) was used to compute the response functions of tree growth to climate by means of a multiple stepwise regression. Coefficients were considered significant at ${ }^{*} p<0.05$ and ${ }^{* *} p<0.01$. A bootstrapped analysis was also applied to improve the robustness of the correlation coefficients. In this analysis, 1000 bootstrap interactions were made. The Kalman filter, which estimates regression models by timevarying coefficients, was applied to determine if climatic variable effect changed over time (Fritts, 1998). The output of this analysis included predicted tree-ring indexes and the confidence interval (95\% level); therefore, when the interval did not include a zero value, the regression coefficient was considered significant (Kalman filter, V5.17 PRECON program).

\section{RESULTS}

\subsection{Chronology description}

Chronology 6a was not included in the analysis because its time span was only 30 years and it would have limited the period analysed of all series. The nine chronologies of Pinus pinaster growing in central Spain are shown in Figure 3. The chronologies had high SNR, EPS and percentage of the variance accounted for the first eigenvector; this suggests that they reflect a strong common signal, presumably related to climatic factors. The descriptive statistics showed that mean sensitivity varied from 0.1857 to 0.3179 and standard deviation varied from 0.1650 to 0.3108 , depending on the sampling site. SNR varied from 27.615 to 68.444 and EPS values varied from 0.958 to 0.986 (Tab. III). All chronologies analysed have high SNR (values always over 22) and EPS (always over 0.95), while the variance accounted by the first eigenvector is over $48 \%$; these findings suggest a strong common signal related to environmental climatic factors (Tab. III). Despite the diversity of tree ages and the difference in bioecological regions, a clear common growth signal expressed by the first principal component (PC1) of the PCA was found. PC1 explained 56\% of the total variance of the nine residual chronologies. All the residual chronologies had a positive correlation with PC1, indicating they shared a common variance (Tab. IV and Fig. 4).

\subsection{Climate growth association: multiple stepwise and bootstrapped analysis}

Radial growth, at both regional and local scales, was strongly associated with climatic variables, especially rainfall during and prior to the growing season in all the sites analysed. Mean temperature effect changed according to the sampling site, from non-significant at the highest sites to significant (positive relationship in winter) at the lowest sites.

As a result of the PCA analysis, PC1 was considered indicative of the inter-annual high-frequency variation of tree-ring growth at regional level for the common period 1952-2005. This chronology was correlated with regional climatic variables, precipitation and temperature, and the results showed that more than $60.8 \%$ of the total variance in radial growth was explained by climate (Fig. 5).

The total variance explained by both climatic variables (monthly rainfall and mean monthly temperature) in the Duriense ecoregion varied from 42 to $50 \%$. Both chronologies 

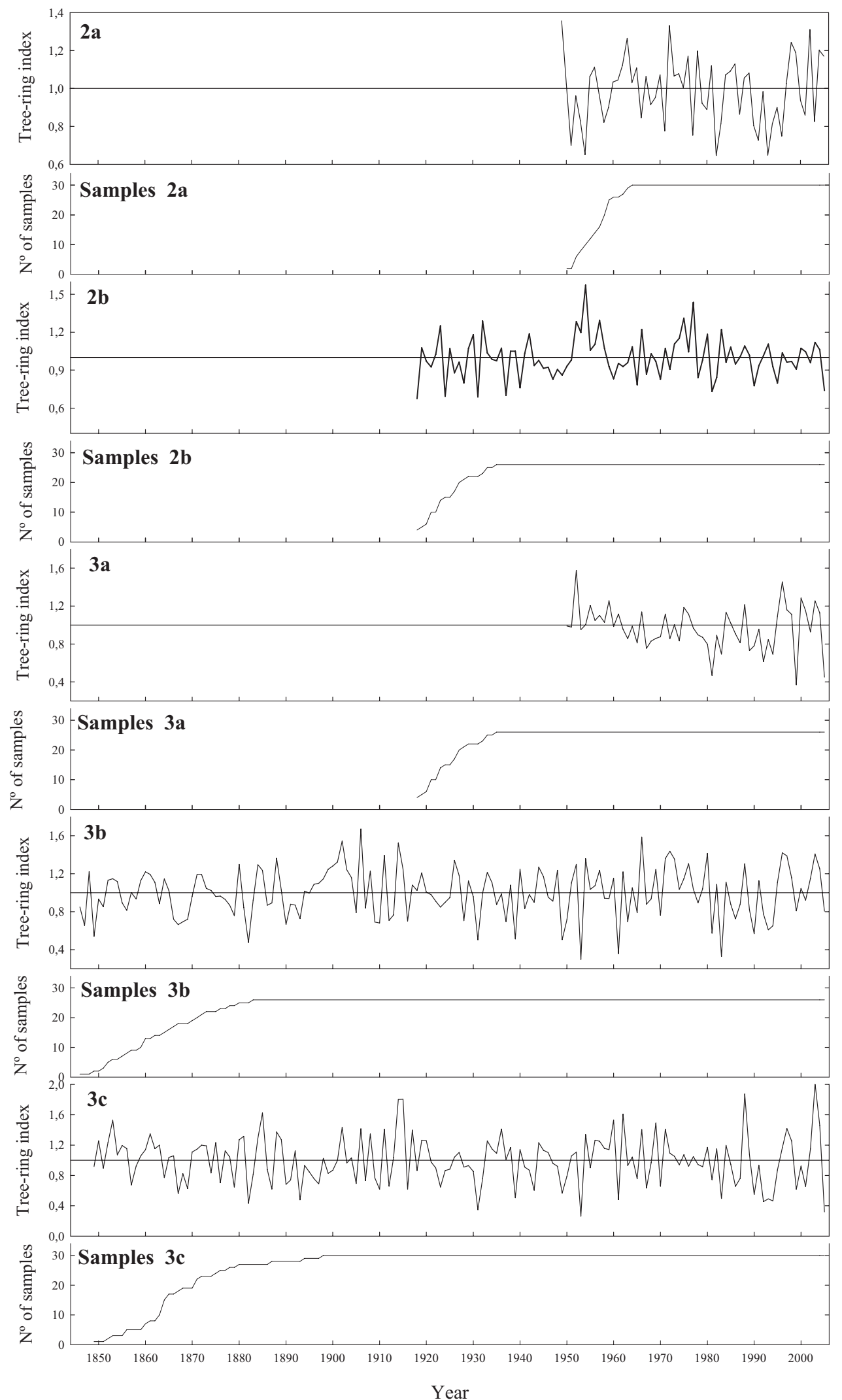

Figure 3. Standardized chronologies of Pinus pinaster along the natural distribution area in Central Spain. The upper part of each figure show the tree-ring indexes through time and the bottom part the number of samples used in each chronology. 

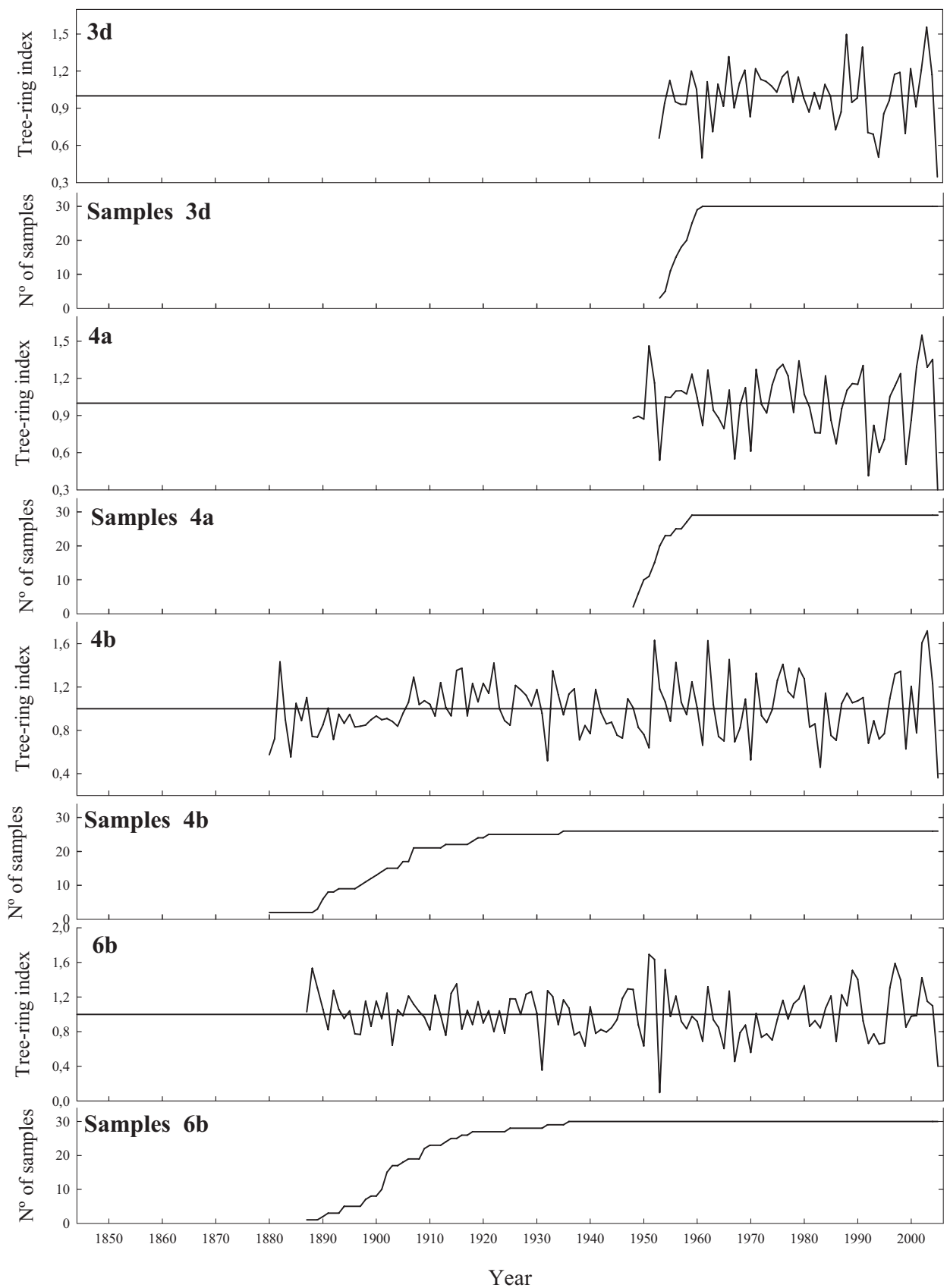

Figure 3. Continued.

were the only ones among all the sites analysed that showed a negative correlation with autumn temperature prior to the growing season; in addition, temperature had a negative effect on growth in later springtime and early summer at both sampling sites (June and July). The impact of rainfall during the growing season was shared among all the sampling sites and, in this ecoregion, it varied from May to June (Site 2a) and from April to June (Site 2b) (Figs. 6, 2a, 2b).

The four chronologies belonging to the CatalanoAragonesa ecoregion showed a clear association with rainfall in August prior to the growing season and during the growing season at all the sampling sites. Sites $3 \mathrm{a}$ and $3 \mathrm{c}$ also showed a positive association with winter rainfall previous to the growing season. Site $3 \mathrm{a}$ was placed at lower altitude $(>200 \mathrm{~m}$.) than the other sites analysed and it was the only one that showed a positive association with temperature in winter (February). This site also had a different behaviour compared with the other sampling sites, showing a negative association with summer temperature (Figs. 6, 3a-3d).

Both chronologies belonging to the Litoral-Mediterránea ecoregion also showed a clear association with rainfall in springtime (April and May at Site 4b), in springtime and 
Table III. Descriptive statistics of the nine Pinus pinaster chronologies in central Spain. SD: standard deviation; MS: mean sensibility; SNR: signal to noise ratio; EPS: expressed population signal; Var.: variance in first eigenvector; and Mean Corr.: mean correlation among trees.

\begin{tabular}{lcccccccccc}
\hline & $2 \mathrm{a}$ & $2 \mathrm{~b}$ & $3 \mathrm{a}$ & $3 \mathrm{~b}$ & $3 \mathrm{c}$ & $3 \mathrm{~d}$ & $4 \mathrm{a}$ & $4 \mathrm{~b}$ & $6 \mathrm{~b}$ \\
\hline Time span & $1946-2005$ & $1916-2005$ & $1947-2005$ & $1844-2005$ & $1847-2005$ & $1952-2005$ & $1947-2005$ & $1879-2005$ & $1886-2005$ \\
Core number & 30 & 27 & 30 & 26 & 29 & 30 & 29 & 26 & 30 \\
Ring number & 1635 & 2228 & 1487 & 3757 & 4128 & 1477 & 1579 & 2723 & 3043 \\
Age range & $44-60$ & $68-90$ & $42-59$ & $131-156$ & $124-158$ & $45-54$ & $48-59$ & $72-127$ & $72-120$ \\
SD & 0.172 & 0.165 & 0.310 & 0.258 & 0.317 & 0.237 & 0.271 & 0.255 & 0.2764 \\
MS & 0.206 & 0.185 & 0.278 & 0.299 & 0.370 & 0.268 & 0.292 & 0.257 & 0.297 \\
SNR & 27.615 & 22.60 & 52.302 & 29.087 & 68.444 & 52.118 & 60.636 & 38.528 & 36.254 \\
EPS & 0.965 & 0.958 & 0.981 & 0.967 & 0.986 & 0.981 & 0.984 & 0.975 & 0.973 \\
Var. & 51.84 & 48.94 & 67.78 & 54.85 & 71.41 & 65.88 & 70.18 & 62.78 & 59.62 \\
Mean corr. & 0.488 & 0.466 & 0.635 & 0.528 & 0.702 & 0.642 & 0.684 & 0.606 & 0.573 \\
\hline
\end{tabular}

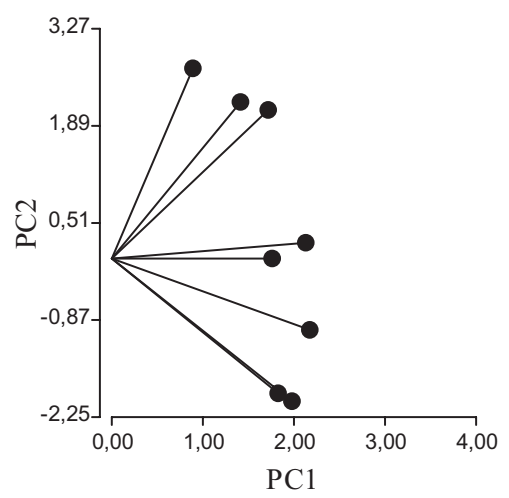

Figure 4. First against second eigenvector loading of the principal component analysis on all Pinus pinaster residual chronologies in central Spain for the common period 1952-2005.

summer in the growing season (March, May and August at Site 4a) and with August rainfall prior to the growing season at both sites. Site $4 \mathrm{~b}$ also showed a positive association with temperature in winter, and high temperature during the growing season (May) may limit growth at Site 4a. Both sampling sites shared a similar variability explained by both variables, which varied between 63 and 64\% (Figs. 6, 4a, 4b).

Finally, Site $6 \mathrm{~b}$ (belonging to the Manchega ecoregion) showed a positive correlation not only with rainfall in May and December, but also with temperature in winter (Fig. 6, 6b).

\subsection{Climate growth association over time: the Kalman filter technique}

Results suggested a changing association between growth and climatic variables from non-significant to significant $\left({ }^{*} p<\right.$ 0.05) at six of the sampling sites. Table V show a summary of the Kalman filter analysis results that includes all the sampling sites and the climatic variables studied.

The change in association between growth and climatic conditions took place during the 80s. During this period, precipitation changed from non-significant to positively significant at four sampling sites. This change occurred in winter
Table IV. Pearson correlation coefficient between the first principal component of the principal component analysis and the residual chronologies of Pinus pinaster $\left({ }^{* *} p<0.01\right.$ and $\left.{ }^{* * *} p<0.001\right)$.

\begin{tabular}{lc}
\hline Chronology & PC1 \\
\hline $2 \mathrm{a}$ & $0.65^{* * *}$ \\
$\mathrm{2b}$ & $0.39^{* *}$ \\
$\mathrm{3a}$ & $0.60^{* * *}$ \\
$\mathrm{3b}$ & $0.78^{* * *}$ \\
$\mathrm{3c}$ & $0.85^{* * *}$ \\
$\mathrm{3d}$ & $0.94^{* * *}$ \\
$4 \mathrm{a}$ & $0.92^{* * *}$ \\
$4 \mathrm{~b}$ & $0.74^{* * *}$ \\
$6 \mathrm{~b}$ & $0.76^{* * *}$ \\
\hline
\end{tabular}

prior to the growing season (December and January, Site 3a) and at the beginning of the growing season (March, Site $4 \mathrm{a}$ or April and May, Sites 3c and 3d). Temperature also showed a changing association with growth at two sampling sites (4a and $6 \mathrm{~b}$ ): temperature became negatively significant on radial growth in springtime (May) at Site 4a. Finally, a positive change was found at Site $6 \mathrm{~b}$ in relation to winter temperature (February). As an example, Figure 7 shows the changing association between radial growth and climatic variables at Site $4 \mathrm{a}$.

\section{DISCUSSION}

Pinus pinaster is a reliable species for dendrochronological studies, showing good correlation between trees growing at the same sampling site, high signal related to total noise and accurate statistical values that mean clear response to environmental factors. This species also shows accurate performance in studying the association between tree growth and global change showed by a changing relationship with climatic variables over time.

The statistics that characterised the chronologies suggest that the tree-ring series accurately reflects one or more causal factors (including climate), shown by the mean sensitivity values (MS) that are similar to the 0.16 to 0.34 values found in previous studies on Pinus sylvestris L., Pinus nigra Arnold, 


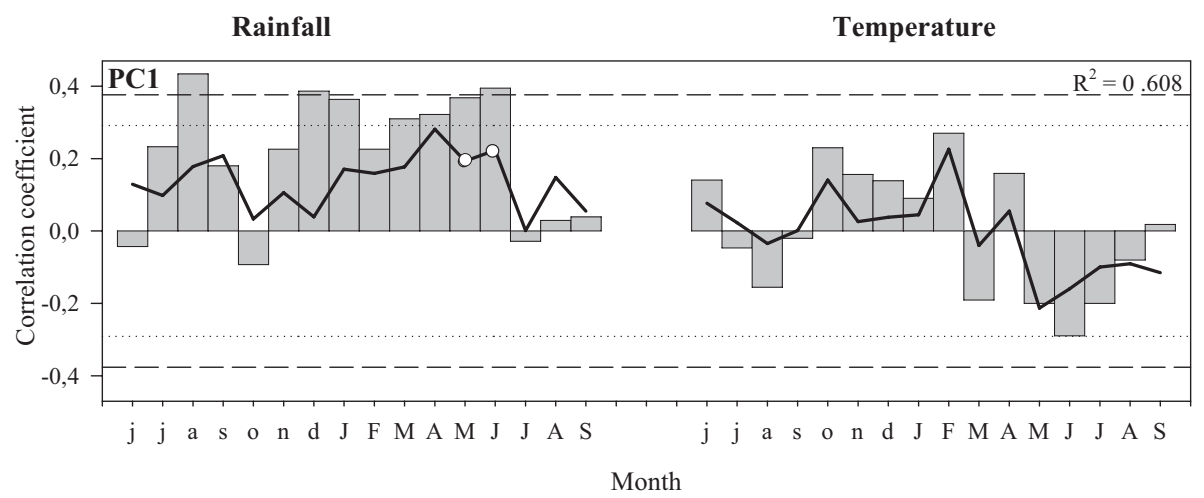

Figure 5. Correlation coefficients (bars) and bootstrapped response function (lines) that indicate the effect of regional climatic variables and growth of Pinus pinaster during the 1960-2005 period. The period analysed covers from June of the year prior to growth to September of the current growing year. Bars outside dashed lines show significant coefficients at $* * p<0.01$. Bars outside dotted lines show significant coefficients at $* p<0.05$. White circles indicate months where the bootstrapped response function coefficients are significant at $p<0.05$. $R^{2}$ values show the total variance explained by both variables. Lower case letters indicate months prior to the growing year. Upper case letters indicate the growing year months.

Pinus pinaster Ait. and Pinus mugo ssp. uncinata Turra. growing in Spain (Richter et al., 1991). Signal-to-noise ratio (SNR) values that vary from 22.6 to 66.44 suggest that the proportion of the explainable variation due to climate or other causal factors divided by the unexplainable variation or residual is sufficiently high for all the sampling sites. Expressed population signal (EPS), ranging from 0.958 to 0.986 , is accurate enough ( $>0.85$ ) for these studies (Wigley et al., 1984); this suggests that these chronologies describe the infinite, hypothetical population of Pinus pinaster at each sampling site well enough. First eigenvector variance ranges from 48.94 to $70.18 \%$, indicating good homogeneity within the same site. Summing up, the nine chronologies have high MS, SNR, EPS and percentage of the variance accounted for by the first eigenvector, suggesting a strong common signal to related-climatic environmental factors.

A common growth pattern among all series has been detected. PCA analysis suggests a clear strong common variance among all the sampling sites (explaining over $56 \%$ of variability) and a positive correlation $\left({ }^{* *} p<0.01\right.$ and $\left.{ }^{* * *} p<0.001\right)$ with the PC1 axis. Although the sampling sites included trees of different ages and trees from different ecoregions, all the series can be considered to share a common variance related to causal factors. These results coincide with a previous study in Spain which suggested that pine species growing in the southern dendroecological section of the Iberian Peninsula (according to the division made by the authors), like eight of the chronologies in this study, could have a common growth response to environmental factors (Richter et al., 1991). PCA applied to analysing three pine species in Spain (Pinus nigra Arnold, Pinus sylvestris L. and Pinus uncinata Ram.) explained $32.5 \%$ of variability among the chronologies (Andreu et al., 2007). Our higher variability (56\%) may be due to the fact that only one pine species was included in this study.

There are previous studies which consider PCA to be adequate for estimating a common growth variance among and within species (Andreu et al., 2007; Girardin and Tardif,
2005). In this study, the PCA analysis results obtained suggest a clear strong common variance among all the sampling sites, indicated by $56 \%$ of the growth variability explained by $\mathrm{PC} 1$. All sampling sites show a significant positive PC1 correlation, suggesting a sound common variance. The high correlation coefficient values (more than 0.6, except for Site 2b) emphasise the common growth pattern among all series. Another fact that explains the high variability shared by the sampling sites is that they were located about $450 \mathrm{~km}$ apart, a figure previously considered as too long a distance to guarantee good cross-dating among different pine chronologies (Richter and Eckstein, 1990).

High correlation on radial growth between individuals of Abies alba Mill. and Picea abies Karst. growing under different environmental conditions was also found in France, suggesting that tree-ring growth is not modified by local site characteristics (Lebourgeois, 2007). The total variance explained by average climatic variables and regional radial growth index of Pinus pinaster (60\%) can be considered appropriate considering tree-rings rarely cover more than $60 \%$ of the variance registered in instrumental records, and 40 to $50 \%$ is quite a common level (Fritts H. 1991; Jones et al., 1998). Richter et al. (1991) found $68 \%$ of the total variance explained by precipitation and temperature in pine species growing in the Iberian Peninsula.

Rainfall is the dominant climatic variable that has a significant association with Pinus pinaster growth, as the stepwise correlation analysis indicated. Rainfall effect constitutes the significant climatic variable in both the regional and local analyses. This could be the reason why all the sites share a high common variance explained by PC1. Other factors, such as genetic provenance or specific plasticity based on physiological adaptations, can interact with precipitation. The importance of precipitation, independently of sampling site location, has also been reported for Pinus sylvestris L., Pinus nigra Arnold. and Pinus pinea L. growing in the Iberian Peninsula (Campelo et al., 2007; Richter, 1988). Rainfall during and prior to the 

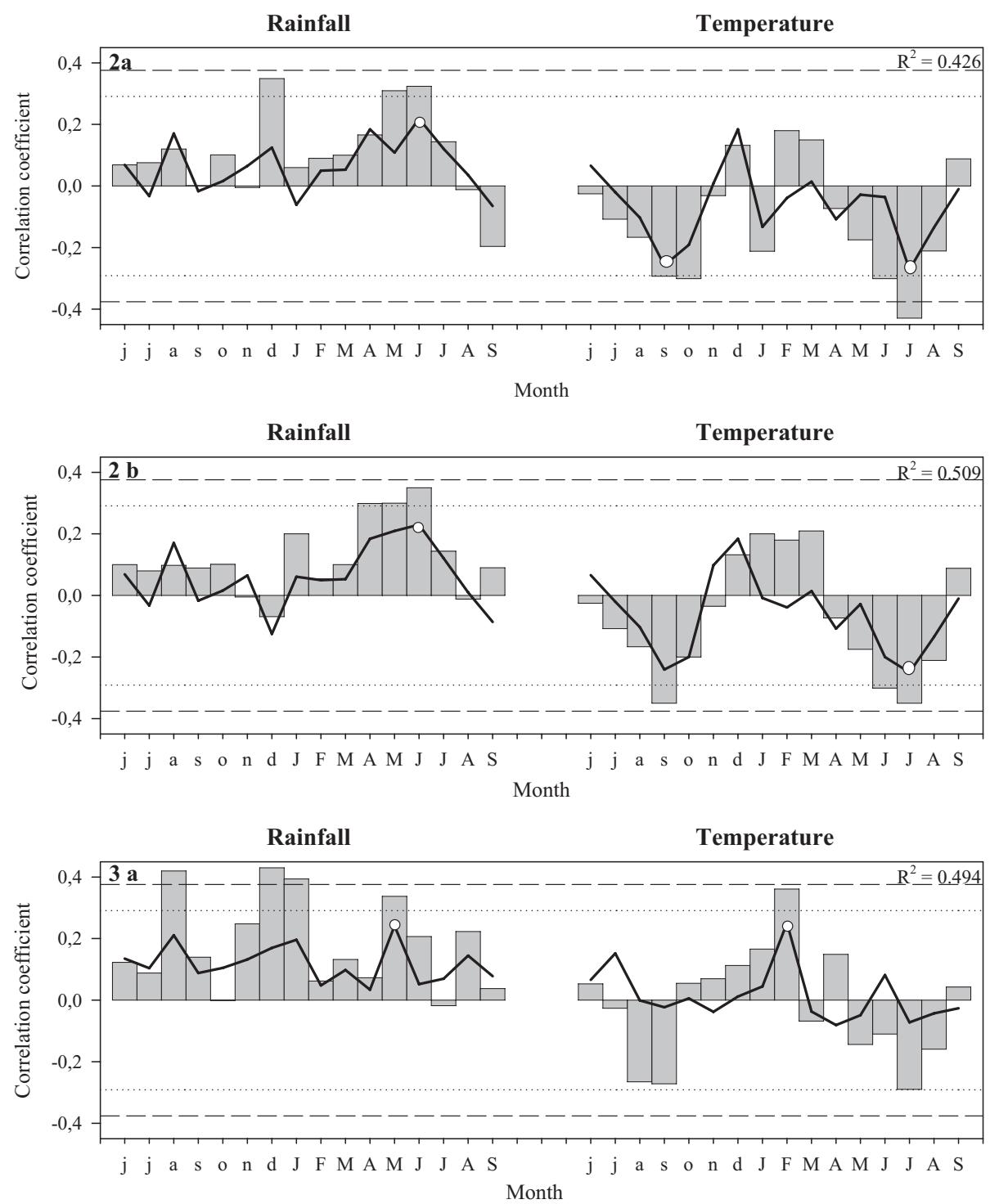

Figure 6. Correlation coefficients (bars) and bootstrapped response function (lines) that indicate the effect of local climatic variables and growth of Pinus pinaster at sites 2a, 2b, 3a, 3b, 3c, 3d, 4a, 4b and 6b during the 1960-2005 period. The period analysed covers from June of the year prior to growth to September of the current growing year. Bars outside the dashed lines show significant coefficient at $* * p<0.01$. Bars outside the dotted lines show significant coefficients at $* p<0.05$. White circles indicate months where the bootstrapped response function coefficients are significant at $* p<0.05$. $R^{2}$ values show the total variance explained by both variables. Lower case letters indicate the months prior to the growing year. Upper case letters indicate the growing year months.

growing season had a positive effect on growth of four different pine species (Pinus sylvestris, Pinus nigra, Pinus mugo spp. uncinata and Pinus pinaster) when they were studied together (Richter et al., 1991). A positive effect of summer rainfall on three pine species (Pinus sylvestris, Pinus nigra and Pinus uncinata) has also been found in the Iberian Peninsula (Andreu et al., 2007).

Precipitation effect on radial or diameter tree growth, especially at young ages, has also been reported for other coniferous species in northern California, concluding that precipitation is the most important factor limiting growth for the six coniferous species analysed (Yeh and Wensel, 2000).
The effect of temperature on tree growth varied among sites. No effect was recorded at the sites placed at the highest positions ( $3 \mathrm{~b}, 3 \mathrm{c}$ and $3 \mathrm{~d}$ ) and a negative effect was recorded at five sampling sites (2a, 2b, 3a, 3d and 4a). A positive temperature effect in winter prior to the growing season (Sites 3a, $4 b$ and $6 \mathrm{~b}$ ) coincided with a previous study made on four pine species that pointed out the positive significant effect of winter temperature (Richter et al., 1991). The difference found out in this study is that temperature effect could not be simplified to a common response in all the sampling sites because local issues, as for example slope or aspect, could determine the association between this variable and radial growth. 

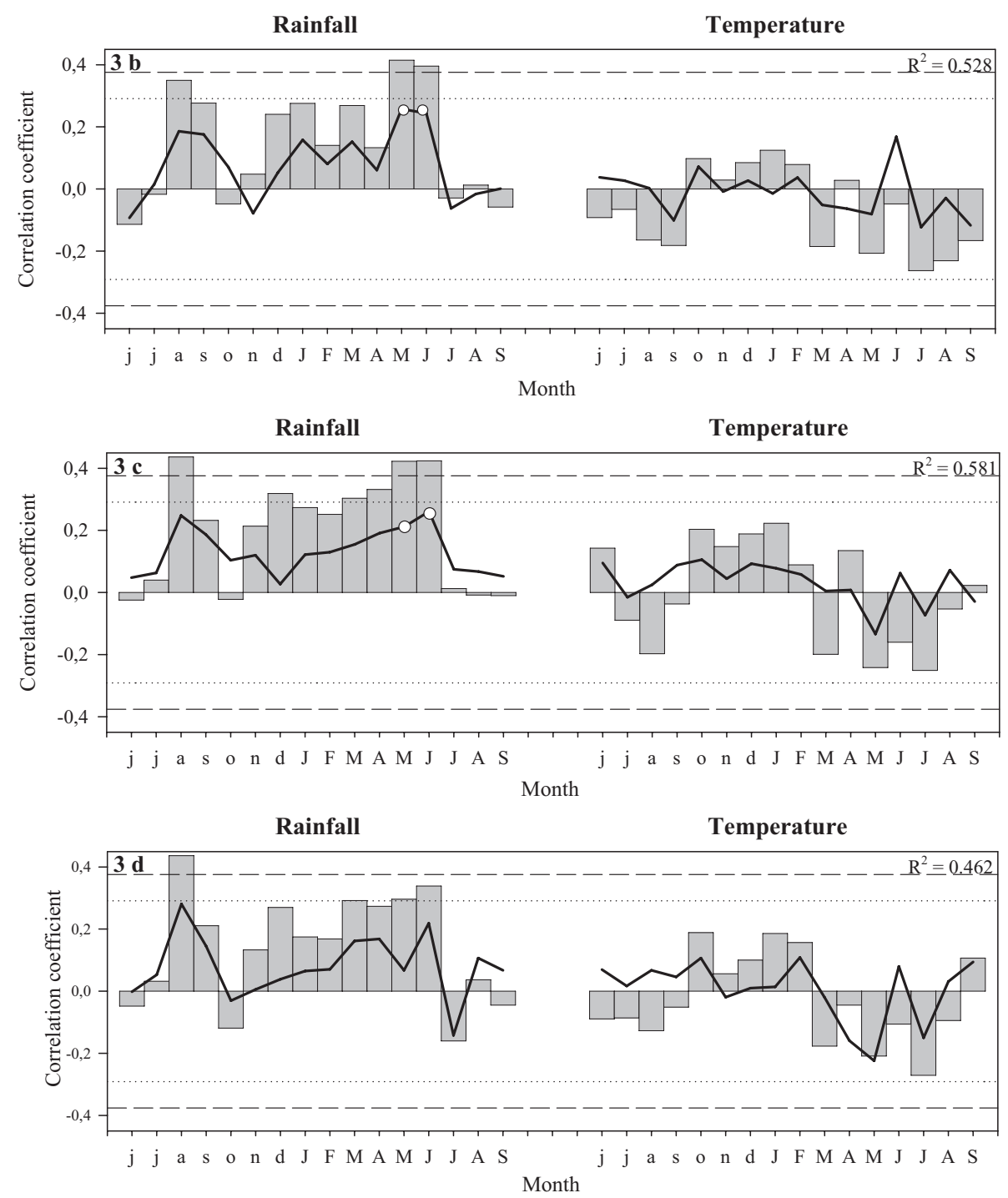

Figure 6. Continued.

Although Richter et al. (1991) did not find significant differences in growth patterns among different pine species using a PCA, they pointed out that the Iberian Peninsula could be divided in two main areas according to climate response (northern and southern). According to this division, all the sampling sites in this study belong to the southern area except for the Duriense ecoregion (northern area); the sampling sites in this ecoregion showed not only similarities with the other sampling sites (rainfall), but also differences, due to it is the only ecoregion that showed a negative association with temperature at the beginning of autumn prior to the growing season.

Pinus pinaster radial growth shows a strong association with precipitation and temperature. Temperature effect is less evident than precipitation. However, intercorrelation between precipitation, temperature and evapotranspiration can limit environmental moisture and, consequently, restrict tree growth. However, the predicted temperature trend until 2080 will probably not lead to an unsuitable environment for Pinus pinaster (Harrison et al., 2006). As Pinus pinaster is a preMediterranean species that has suffered different environmental changes (from subtropical environments to Mediterranean ones) (DiCarlo, 1931), it can also deal with very atypical severe droughts, such as that of 1994 (Peñuelas et al., 2002), and it shows a better water-use efficiency than Pinus sylvestris (Martínez-Vilalta and Piñol, 2002). These facts indicate that Pinus pinaster might be well adapted to summer rainfall reductions.

A change in growth response in different pine species as a response to climatic conditions has been reported (Andreu et al., 2007). Results show a changing climate effect on growth and some variables that were non-significant 30 years ago have been stated to be significant since the 1980s. The climatic warming of the 1980-1995 period was characterised by intense droughts that produced severe damage in woody species (Peñuelas et al., 2001). Our findings indicate that some climatic variables (May temperature and April-May 

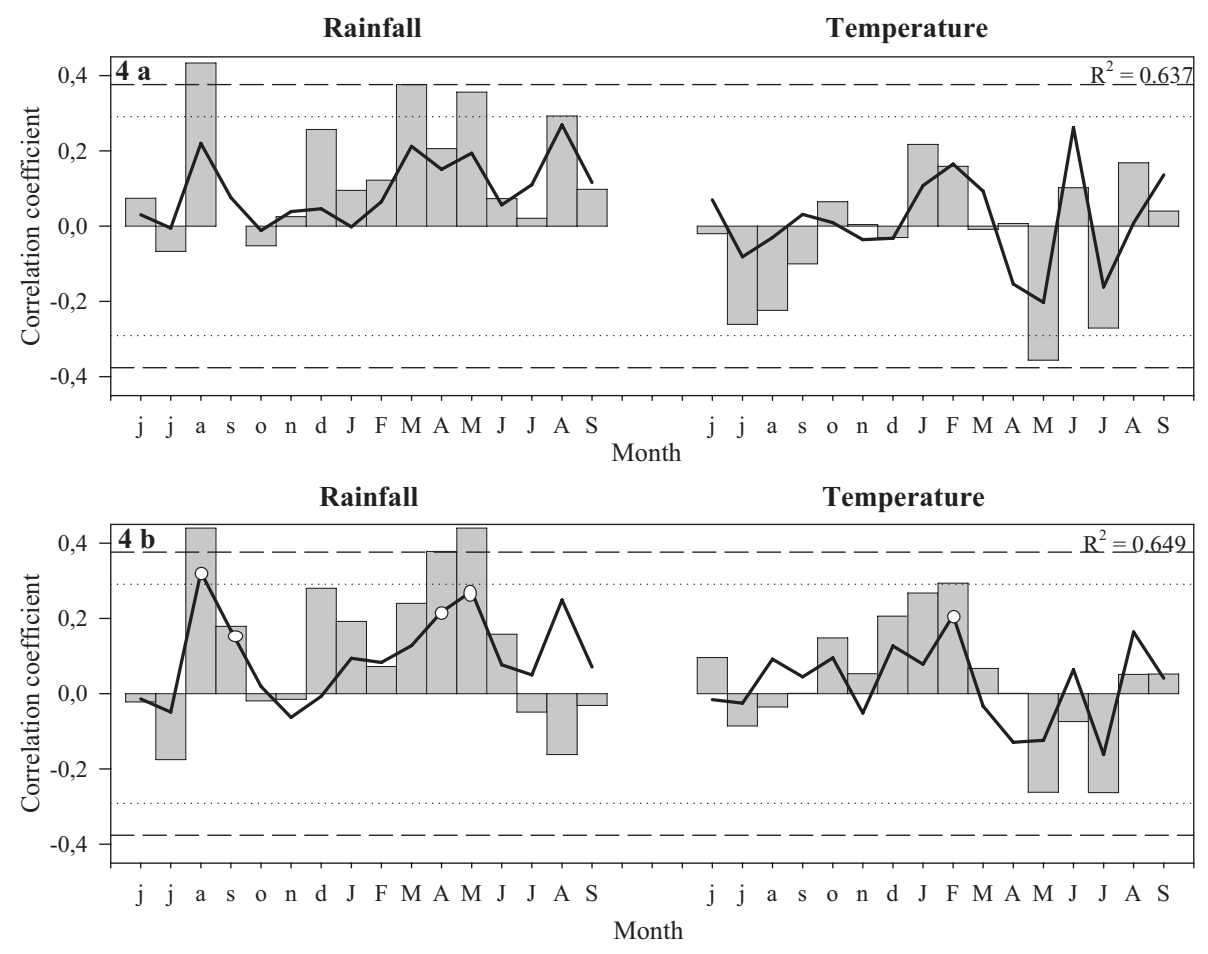

Rainfall

Temperature

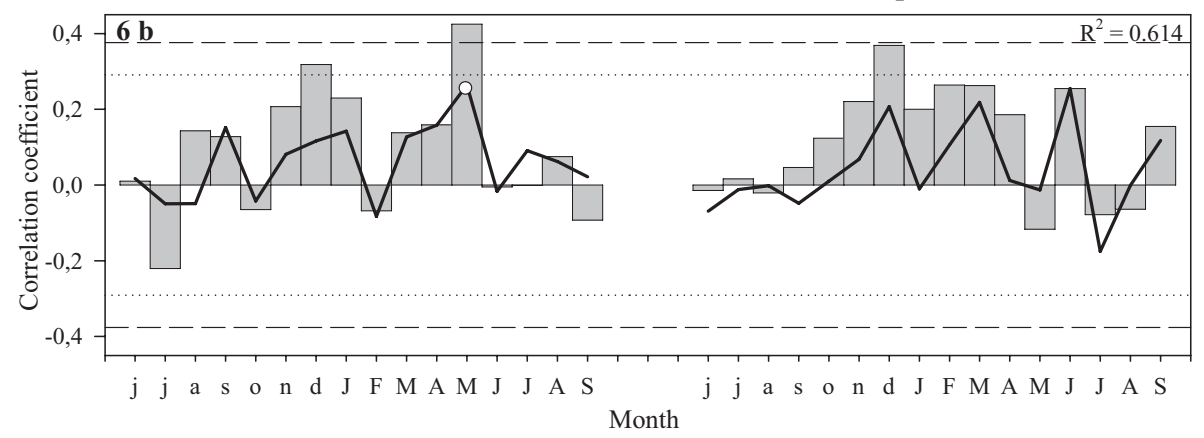

Figure 6. Continued.

Table V. Kalman filter analysis results between Pinus pinaster radial growth and monthly climate variables (mean temperature and rainfall) at all the sampling sites.

\begin{tabular}{|c|c|c|c|c|c|c|c|c|c|c|c|c|c|c|c|c|}
\hline Site & Jun & Jul & Aug & Sep & Oct & Nov & Dec & Jan & $\mathrm{Feb}$ & Mar & $\mathrm{Apr}$ & May & Jun & Jul & Aug & Sep \\
\hline $2 a$ & & & & $\mathrm{~T}$ & $\mathrm{~T}$ & & $r$ & & & & & $r+$ & $r \mathrm{~T}$ & & & \\
\hline $2 b$ & & & & $\mathrm{~T}$ & & & & & & & $r$ & $r$ & $r \mathrm{~T}$ & $\mathrm{~T}$ & & \\
\hline $3 a$ & & & $r$ & & & & $r+$ & $r+$ & $t$ & & & $r$ & & $\mathrm{~T}$ & & \\
\hline $3 b$ & & & $r$ & & & & & & & & & $r$ & $r$ & & & \\
\hline $3 c$ & & & $r+$ & & & & $r$ & & & $r$ & $r+$ & $r+$ & $r$ & & & \\
\hline $3 d$ & & & $r+$ & & & & & & & $r$ & $r+$ & $r+$ & $r$ & & & \\
\hline $4 a$ & & & $r$ & & & & & & & $r+$ & & $r \mathrm{~T}+$ & & & $r$ & \\
\hline $4 b$ & & & $r$ & & & & & & $t$ & & $r$ & $r$ & & & & \\
\hline $6 \mathrm{~b}$ & & & & & & & $r t$ & & $t+$ & $t$ & & $r t$ & & & & \\
\hline
\end{tabular}

Letters indicate the months where the association was statistically significant $\left({ }^{*} p<0.05\right)$ : lower-case $r$ means monthly rainfall, and the letter $t$ means mean monthly temperature. Capital letters refer to a negative association with climate variables. Letters with (+) symbol indicate the months when the association changed over time. 


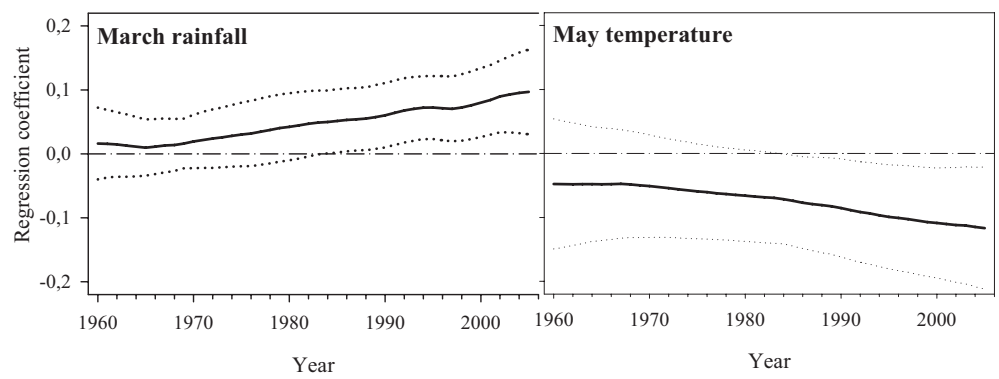

Figure 7. Kalman filter analysis results for the time-dependent relationships between radial growth and climatic variables (March rainfall and May temperature) at Site 4a. The solid lines show the regression coefficient and the dotted lines are the confidence intervals at a 95\% confident level.

rainfall) have changed from non-significant to significant in the last 30 years (from 1980 until now). This coincides with previously-reported phenological changes in plant life (related to temperature) in the Mediterranean region. In addition, these changes started during the 80 s, which could mean a changing association with climatic factors (Peñuelas et al., 2001; 2002).

Summing up, Pinus pinaster radial growth is strongly associated with water supply, which means that it could be an excellent tool for reconstructing past weather conditions in the Iberian Peninsula, especially the temporal fluctuations of rainfall. On the other hand, a changing association between growth and climatic variables has shown that this species could be a good candidate as accurate tool for studying global change effect on tree growth.

Acknowledgements: The authors thank Cristotal Ordóñez for field assistance, María José Fernández Nieto for providing meteorological data and Dr. Vicente Rozas, Dr. Estetan Jobbágy and Dr. Mariano Morales; the editor and two anonymous referees for their useful comments. Thanks are also extended to Etienne Cartuyvels, Cinnamon Nolan and María Laura Cangiano for improving the French and English versions. This study was supported by Research projects from the Regional Castilla y León government (Spain) (Project Code VA096A05), the Spanish Ministry of Science and Education (Project Code AGL2007-65795-C02-01) and by the Al $\beta$ an Programme, the European Union Programme of High Level Scholarships for Latin America (Scholarship No. E05D049920AR).

\section{REFERENCES}

Alía M., Martín S., De Miguel J., Galera R., Agúndez D., Gordo J., Catalán G., Gil L., 1996. Regiones de procedencia Pinus pinaster Aiton., Dirección general de Conservación de la Naturaleza, Madrid, $75 \mathrm{p}$.

Andreu L., Gutiérrez E., Macias M., Ribas M., Bosch O., and Camarero J., 2007. Climate increases regional tree-growth variability in Iberian pine forest. Glob. Chang. Biol. 13: 804-815.

Bakkenes M., Alkemade J.R.M., Ihle F., Leemansand R., and Latour J.B., 2002. Assessing effects of forecasted climate change on the diversity and distribution of European higher plants for 2050. Glob. Chang. Biol. 8: 390-407.

Blanco E., Casado M., Costa M., Escribano R., Gracía Antón M., Génova M., Gómez Manzaneque G., Gómez Manzanaque F., Moreno J., Morla C., Regato P., and Sainz Ollero H., 1997. Los bosques ibéricos, Editorial Planeta, Barcelona, España, 572 p.
Briffa K.R., 1995. Interpreting high-resolution proxy climate data-the example of dendroclimatology. In: von Storch H. and Navarra A. (Eds.), Analysis of climate data variability, application of statistical techniques, New York, Springer, pp. 77-94.

Campelo F., Nabais C., Freitas H., and Gutiérrez E., 2006. Climatic significance of tree-ring width and intra-annual density fluctuations in Pinus pinea from a dry Mediterranean area in Portugal. Ann. For. Sci. 64: 229-238.

Cook E.R. and Holmes R.L., 1984. Program ARSTAN users manual. Lab. Tree Ring. Res. Univ. of Arizona, Tucson, Arizona, EUA.

Cook E.R. and Kairiuskstis L.A., 1990. Methods of Dendrochronology, Applications in the Environmental Sciences. Kluwer Academic Publishers, $393 \mathrm{p}$.

D'Arrigo R.D. and Jacoby G.C., 1992. A tree-ring reconstruction of New Mexico winter precipitation and its relation to El Niño/Southern Oscillation events. In: Diaz H.F. and Markgraf V. (Eds.). El Niño. Historical and paleoclimatic aspects of the Southern Oscillation. Cambridge, University Press, pp. 243-258.

DGCN, 1998. Segundo Inventario Forestal Nacional 1986-1996. Ed. Ministerio de Medio Ambiente, España.

DGCN, 2002. Plan Forestal Español. Ed. Ministerio de Medio Ambiente, España.

Di Castri F., 1981. Mediterranean-type shrublands of the world. In: di Castri F., Goodall D., and Specht R.L. (Eds.), Mediterraneantype shrub lands, Elsevier Scientific Publishing Amsterdam, The Netherlands, $643 \mathrm{p}$.

Di Rienzo J., Balzarini M., Casanoves F., Gonzalez L., Tablada E., and Robledo C., 2002. Infostat Software Estadístico versión 2. Grupo infoStat, FCA, Universidad Nacional de Córdoba, Argentina.

Elena-Roselló R., 1997. Clasificación biogeoclimática de España Peninsular y Balear Madrid: Ministerio de Agricultura, Pesca y Alimentación, Madrid, 100 p.

Esteban-Parra M., Rodrigo F., and Castro Diéz Y., 1998. Spatial and temporal patterns of precipitation in Spain for the period 1880-1992. Int. J. Climatol. 18: 1557-1574.

Fritts H., 1976. Tree Ring and Climate, Academic Press Inc., London, $567 \mathrm{p}$.

Fritts H., 1991. Reconstructing large-scale climatic patterns from treering data, The University of Arizona Press, Tucson, USA, 286 p.

Fritts H.C., 1998. Factors preconditioning growth with Kalman filter: an empirical model of the tree ring response to monthly variations in climate. Laboratory of tree-ring research, University of Arizona, Tucson, USA.

Fritts H.C., 1999. PRECON version 5.17, http://www.arizona.edu/webhome/hal/dlprecon.html. 
Fritts H.C. and Swetnam T., 1989. Dendroecology: a tool for evaluating variations in past and present forest environments. Adv. Ecol. Res. 19: $111-188$.

Girardin M. and Tardif J., 2005. Sensitivity of tree growth to the atmospheric vertical profile in the Boreal Plains of Manitoba, Canada. Can. J. For. Res. 35: 48-64.

Grissino-Mayer H.D., 2001. Evaluating crossdating accuracy: a manual and tutorial for the computer program COFECHA. Tree-Ring Res. 57: $205-221$.

Harrison P., Berry P., Butt N., and New M., 2006. Modelling climate change impacts on species' distributions at the European scale: implications for conservation policy. Environ. Sci. Policy 9: 116-128.

Holmes R.L., 1983. Computer-assisted quality control in tree-ring dating and measurement. Tree-ring Bull. 43: 69-78

Holmes R.L., 2001. Dendrochronology Program Library. Available from the Laboratory of Tree Ring Research, University of Arizona, Tucson, USA.

Hughes M., 2002. Dendrochronology in climatology - the state of the art. Dendrochronologia 20: 95-116.

IPCC, 2007. Fourth Assessment Report of the Intergovernmental Panel on Climate Change. Cambridge University Press, Cambridge, United Kingdom and New York, NY, USA.

Jones P.D., Jónsson T., and Wheeler D., 1997. Extension to the North Atlantic Oscillation using early instrumental pressure observations from Gibraltar and South-West Iceland. Int. J. Climatol. 17: 14331450 .

Jones P.D., Briffa K.R., Barnett T.P., and Tett S.F.B., 1998. Highresolution palaeoclimatic records for the last millennium: interpretation, integration and comparison with General Circulation Model control-run temperatures. Holocene 8: 455-471.

Lebourgeois F., 2007. Climatic signal in annual growth variation of silver fir (Abies alba Mill.) and spruce (Picea abies Karst.) from the French Permanent Plot Network (RENECOFOR). Ann. For. Sci. 64: 333 243.

Martínez-Vilalta J. and Piñol J., 2002. Drought-induced mortality and hydraulic architecture in pine populations of the NE Iberian Peninsula. For. Ecol. Manage.161: 247-256.

Nicolas A. and Gandullo J., 1967. Ecología de los pinares españoles. 1, Pinus pinaster Ait. Ministerio de Agricultura, Madrid, España, $311 \mathrm{p}$.
Parry M., 2000. Assessment of potential effects and adaptations for Climate change in Europe: The Europa ACACIA Projet. Jackson Environments Institute, University of East Anglia, Norwich, UK.

Peñuelas J., Lloret F., and Montoya R., 2001. Severe drought effects on Mediterranean Woody Flora in Spain. For. Sci. 47: 214-218.

Peñuelas J., Fillela I., and Comas P., 2002 Change plant and animal life cycles from 1952 to 2000 in the Mediterranean region. Glob. Chang. Biol. 8: 531-544

Regent Instrument Inc., 2002. Windendro ${ }^{\mathrm{TM}}$ v. 2002a, Québec, Qc.

Richter K.,1988. Dendrochronologische und dendroklimatologische Untersurchungen an Kiefern (Pinus sp.) in Spanien. Diss., Universität Hamburg, 296 p.

Richter K. and Eckstein D., 1990. A proxi summer rainfall record for southeast Spain derived from living and historical pine trees. Dendrochronologia 8: 67-82.

Richter K., Eckstein D. and Holmes R.L., 1991. The dendrochronological signal of pine trees (Pinus spp.) in Spain. Tree-Ring Bull. 51: 1-13.

Rodrigo F., Esteban-Parra M., Pozo-Vázquez D., and Castro-Diéz Y., 2000. Rainfall variability in southern Spain on decadal to centennial time scales. Int. J. Climatol. 20: 221-732.

Schweingruber F.H., 1993. Trees and wood in Dendrochronology, Springer series in Wood Science, Springer-Verlag, $474 \mathrm{p}$.

Schweingruber F.H., 1996. Tree rings and environment: Dendroecology, Paul Haupt Publisher, Berne, Sttutgart, Vienna, 602 p.

Sokal R.R. and Rohlf F.J., 1995. Biometry: the principles and practice of statistics in biological research, 3rd ed., WH Freeman and Co., New York, USA, 358 p.

Stokes M. and Smiley T., 1968. An Introduction to Tree-Ring Dating, University of Arizona Press, Tucson, USA, 120 p.

Tessier L., Guibal F., and Schweingruber F., 1997. Research strategies in dendroecology and dendroclimatology in mountain environments. Clim. Chang. 36: 499-517.

Wigley T.M.L., Briffa K.R., and Jones P.D., 1984. On the average value of correlated time series, with applications in dendroclimatology and hydrometeorology. J. Appl. Meteorol. Climatol. 23: 201-213.

Yen H. and Wensel L., 2000. The relationship between tree diameter growth and climate for coniferous species in northern California. Can. J. For. Res. 30: 1463-1471. 